IRA-International Journal of Technology \& Engineering ISSN 2455-4480

Proceedings of the

International Conference on Science \& Engineering for Sustainable Development(2017)

Pg. no.79-92

Published by: Institute of Research Advances https://research-advances.org/index.php/IRAJTE

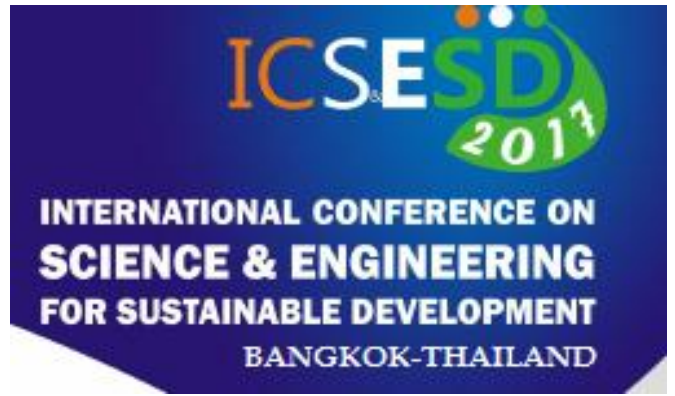

\title{
Impact of Treated Domestic Sewage Irrigation on Crop Yield, Plant Uptake and Soil Properties in Central India
}

\author{
A.R. Mhaske* ${ }^{1}$ P. J. Nikam ${ }^{2}$ \\ ${ }^{*} 1,2$ Agricultural Engineering Section, College of Agriculture, Nagpur \\ Affiliated to Dr. Panjabrao Deshmukh Krishi Vidyapeeth, Akola- 444104 \\ Email ID:mhaskear@gmail.com
}

Type of Review: Originality Check \& Peer Review under the responsibility of the Scientific Committee of the Conference and The Institution of Engineers (India). DOI: http://dx.doi.org/10.21013/jte.ICSESD201708

\section{How to cite this paper:}

Mhaske, A., Nikam, P. (2017). Impact of Treated Domestic Sewage Irrigation on Crop Yield, Plant Uptake and Soil Properties in Central India. Proceedings of the International Conference on Science \& Engineering for Sustainable Development (2017), 79-92. doi: http://dx.doi.org/10.21013/jte.ICSESD201708

(C) International Conference on Science \& Engineering for Sustainable Development\& The Institution of Engineers (India).

\section{(c) $\overline{\text { EY-NC }}$}

This work is licensed under a Creative Commons Attribution-Non Commercial 4.0 International License subject to proper citation to the publication source of the work.

Disclaimer: The conference papers as published by the Institute of Research Advances (IRA) are the views and opinions of their respective authors and are not the views or opinions of the IRA. The IRA disclaims of any harm or loss caused due to the published content to any party. 


\section{ABSTRACT}

The rising population has not only increased the fresh water demand but also increased the volume of wastewater generated. Increasing need for water has resulted in the emergence of domestic wastewater application for agriculture and its relative use. In the present study a field experiment was conducted during 2012-13 and 2013-14 in which spinach (Spinacia oleracia) were irrigated with well water (WW) and domestic treated sewage water (DTSW). The use of the DTSW has shown improvement in the physicochemical properties of the soil, yield along with the nutrient status as compared to the application of WW. Post harvest pH of the soil in DTSW was in the range 7.85 whereas it was 7.93 in WW. EC and OC were found $0.43 \mathrm{dS} \mathrm{m} \mathrm{m}^{-1}$ and $5.41 \mathrm{~g} \mathrm{~kg}^{-1}$ respectively in DTSW whereas it was $0.31 \mathrm{dS} \mathrm{m} \mathrm{m}^{-1}$ and $5.27 \mathrm{~g}$ $\mathrm{kg}^{-1}$ respectively in $W W$. NPK were found $279.6,17.22$ and $435.70 \mathrm{~kg} \mathrm{ha}^{-1}$ respectively in DTSW whereas it was found, 266.8, 16.44 to $428.1 \mathrm{~kg} \mathrm{ha}$-1 respectively in $W W$. The physical properties of the soil like $B D$ and $\mathrm{HC}$ observed $1.32 \mathrm{Mg} \mathrm{m}^{-3}$ and $1.50 \mathrm{~cm} \mathrm{hr}^{-1}$ respectively in DTSW and it was found $1.42 \mathrm{Mg} \mathrm{m}^{-3}$ and $1.54 \mathrm{~cm} \mathrm{hr}^{-1}$ respectively in WW. The content of micronutrients and heavy metals in soil and plant due to irrigation of DTSW were well below the phytotoxicity limits in both soil and plant. The findings give applicable advice to commercial farmers and agricultural researchers for proper management and use of treated domestic wastewater for agricultural purpose.

Keywords: Treated sewage irrigation, Plant uptake, Heavy metals, Micronutrient.

\section{Introduction}

Changing scenario with the economic development of the society towards large-scale urbanization and industrialization is leading to production of huge quantities of wastewater in India. Industrial and domestic effluents are either used or disposed off on land for irrigation purposes that create both opportunities and problems. Opportunities exist as sewage effluents from municipal origin are rich in organic matter and also contain appreciable amounts of major and micronutrients (, Gupta et al. 1998, Brar et al. 2000). Accordingly nutrient levels of soils are expected to improve considerably with continuous irrigation with sewage (Yadav et al. 2002). Again sewage effluents may contain variable amounts of heavy metals, which may limit the long-term use of effluent for agricultural purposes as a likelihood of phytotoxicity and environmental effects. Water is an indispensable resource that permeates every aspect of human society affects every man, women and child. Sewage water is an untouched source of water in India and abroad and if treated through the phytorid wetland engineering technology can became a good water resource and increase water potential which can be used for agricultural irrigation and reduce the burden on the fresh water and the cost of fertilizers with sustainable protection to degradation of environmental resources.

Water is a vital resource but a severely limited in most countries. The population is growing by geometric mean and food demand is increasing with arithmetic means but water availability is constant and to feed sufficiently to people of India, increase in irrigation is the need of the day. Rapid industrial developmental activities and increasing population growth had declined the resources day to day throughout the world. Therefore, there is an urgent need to conserve and protect fresh water and to use the water of lower quality for irrigation Al-Rashed et al.(2000). Treated or recycled wastewater (RWW) appears to be the only water resource that is increasing as other sources are dwindling USEPA.1992.

Consequently the reuse of wastewater for agriculture is highly encouraged (Mohammad and Mazahreh, 2003). The reuse of wastewater for agricultural irrigation purposes reduces the amount of water that needs to be extracted from water resource Gregory, 2000. It is the potential solution to reduce the freshwater demand for zero water discharge avoiding the pollution load in the receiving sources. It is the necessity of the present era to think about the existing urban wastewater disposal infrastructure, wastewater agriculture 
practices, quality of water used, the health implications and the level of institutional awareness of wastewater related issued Rutkowski et al.2006.

Indiscriminate disposal of such water is a cause for pollution of air, soil and groundwater supplies. Cost of treatment of domestic wastewater for recycling is too high to be economically unfeasible in developing countries like India. However, such wastewater exerting most of the nutrient load and could be used as irrigation water to certain crops, tree and plants that may lead to increase in agricultural produce and plantation. It has a potential to supply (organic) carbon nutrients nitrogen, phosphorus, potassium (NPK) and (inorganic) micro nutrients to support crop/plant growth [Weber, 1996].

In the agriculture practices, the irrigation water quality is believed to have an effect on the soil characteristics, crops production and management of water. Application of saline /sodic water results in the reduction of crop yield and deterioration of the physico-chemical characteristics of soil. Present study deals with application of domestic treated sewage water for irrigation and its effect on soil characteristics.

\section{Materials and Methods}

\section{Site Description:}

An experimental setup was made for conducting the study to investigate the effects of application of DTSW and WW on pollutant uptake of the crop and yield. Field experiments were conducted during the year 2012-13 and 2013-14 at agriculture farm, Agriculture College, Maharajbag, Nagpur situated at $21.14^{\circ} \mathrm{N}$ and $79.090^{\circ} \mathrm{E}$ and an altitude of about 312 meters above mean sea level. Research work was carried out using treated sewage water generated from the Phytorid based sewage treatment plant which comprises wetland engineering technology was installed and commissioned during June-2012 on the Nag river passing through the Agriculture College Farm Maharajbag under Dr. Panjabrao Deshmukh Krishi Vidyapeeth at Nagpur (Fig.1).

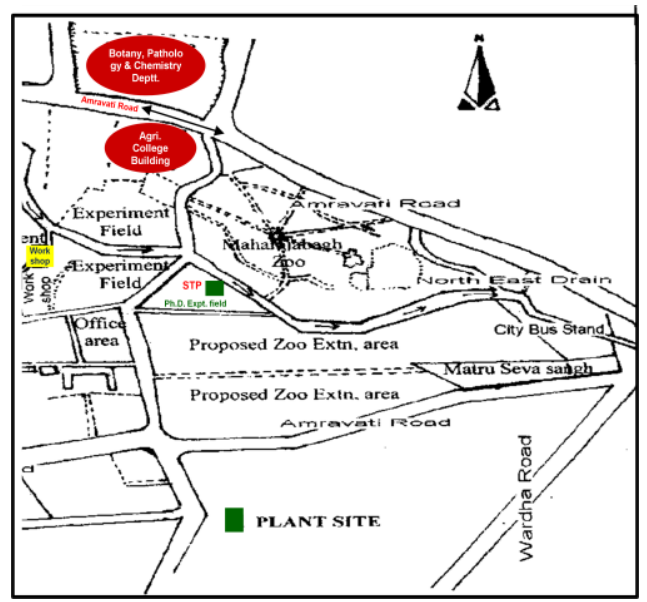

Fig.1: Location map of Nag river, phytorid sewage treatment plant and crop experimental site

The experiment was a factorial, completely randomized design with two main treatments of DTSW ( $\left.\mathrm{T}_{1}\right)$ and WW $\left(\mathrm{T}_{2}\right)$. Each treatment had ten replications. Vegetable crop spinach was grown by dibbling method and crops were irrigated with DTSW and WW @ 5 ha cm per irrigation and allowed to grow till maturity. The meteorology of the study area indicated the temperature range from $10-28.6{ }^{\circ} \mathrm{C}$ to $30.7-$ $44.5{ }^{\circ} \mathrm{C}$ in winter and summer respectively with annual rainfall $1145 \mathrm{~mm}$ and humidity from 10 to $88 \%$. The soil at the experimental site is having texture class of $57.43 \%$ clay, $19.25 \%$ silt, $14.90 \%$ fine sand and $8.46 \%$ coarse sand. 


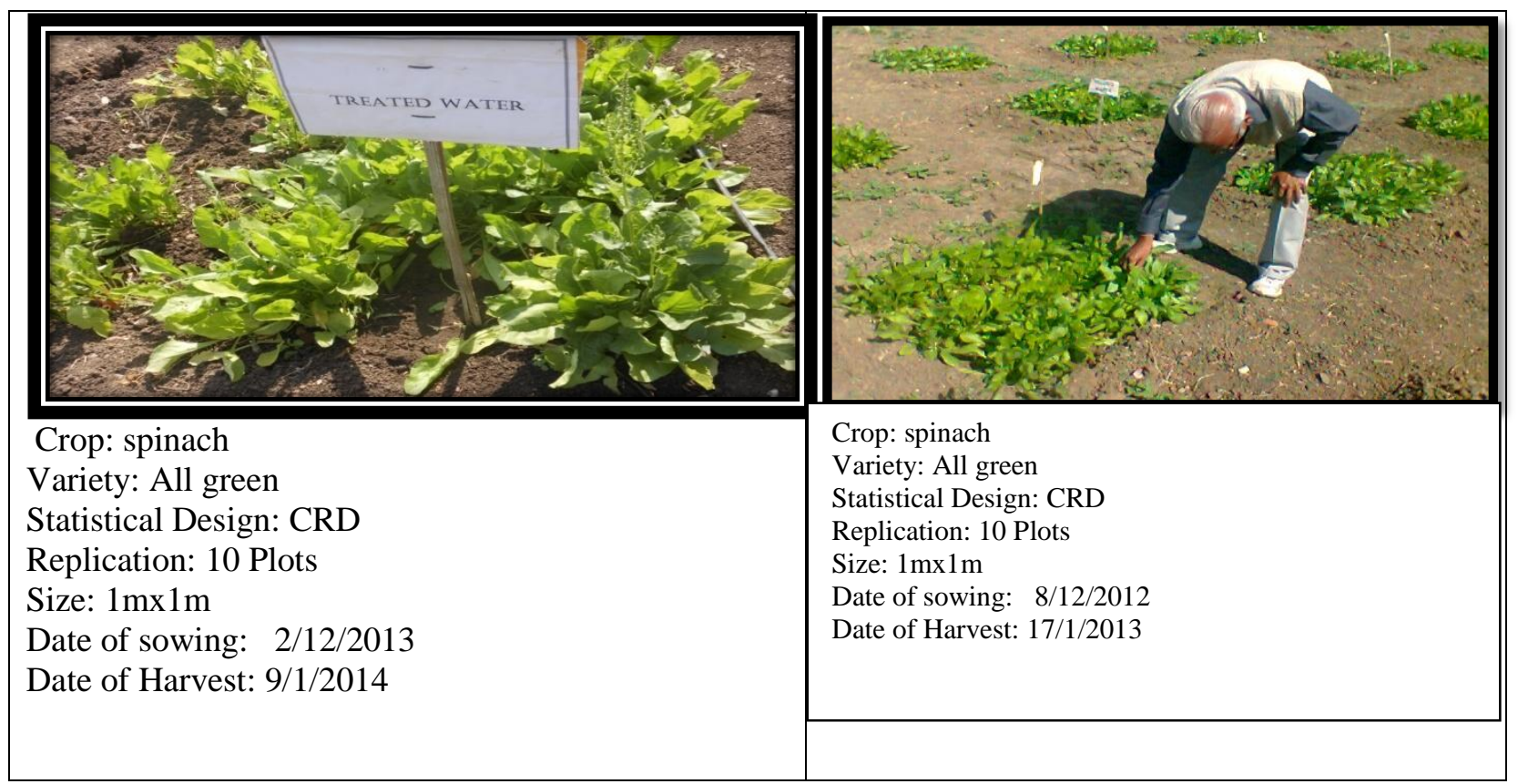

Fig.2. Plates of spinach along with the details during two years

\section{Sampling of domestic wastewater and fresh water:}

The DTSW was collected from phytorid sewage treatment plant, at Nag river, at Agriculture College, Nagpur (India). WW was collected from the well at Maharajbag garden at Agriculture College, Nagpur nearby field. Samples of DTSW from treatment plant were collected two times during the study period in pre-sowing and after harvesting field crops.

\section{Methods of analysis for DTSW and WW:}

The $\mathrm{pH}$ of the samples was determined using the $\mathrm{pH}$ meter, by calibrating the $\mathrm{pH}$ meter using the buffer solutions of known $\mathrm{pH}$ values (Potentiometric method-1985). Electrical conductivity (EC) was determined using the Conductivity Meter (Conductrometric Method) calibrated with conductivity standard $\left(0.01 \mathrm{~m} \mathrm{KCl}\right.$ with conductivity $\left.1413 \mu \mathrm{Scm}^{-1}\right)$ APHA (1985). Biological oxygen demand was determined by Winkler titration method APHA (1985). Chemical oxygen demand was determined by Reflux method APHA (1985). Total dissolved solids and Total suspended solids were determined by Gravimetric method APHA (1985). Phosphate was determined by Vanadomolybdate phosphoric acid (colorimetric) method APHA (1985). Available nitrogen was estimated by Kjeldhal method. Total Nitrogen was determined using the Kjeldahl procedure (Bremner and Mulvaney, 1982). Turbidity was determined by Nephelometric method (APHA 1985). Micronutrient and heavy Metal was determined by Atomic Absorption Spectrophotometric method Page et al. (1982).

\section{Soil sample collection and analysis:}

The composite surface soil sample $(0-15 \mathrm{~cm})$ was collected from experimental site prior to the start of the field experiment. After harvest of the crop, treatment wise soil samples were collected, air dried and ground to pass through $2 \mathrm{~mm}$ sieve and stored in plastic bottles before analysis. The samples were analyzed for different physical and chemical properties as per the standard procedure. International pipette method was used to determine the individual soil fraction i.e. sand, silt and clay (Piper, 1996). The $\mathrm{pH}$ of the samples was determined using the $\mathrm{pH}$ meter; by calibrating the $\mathrm{pH}$ meter using the buffer 
solutions of known $\mathrm{pH}$ values (Potentiometric method-1985) .Electrical conductivity (EC) was determined using the Conductivity Meter (ELICO Conductivity Bridge). Soil organic carbon was estimated by Walkley-Black method (Jackson, 1967), Phosphate was determined by extracting the soil with Olsen's reagent $0.5 \mathrm{~m} \mathrm{NaHCO}_{3}$ of $\mathrm{pH} 8.5$ and in the extract, available $\mathrm{P}$ was estimated calorimetrically (Jackson 1967). Available potassium estimated by leaching the soil with in ammonium acetate and the determination of potassium by using flame photometer as per the standard method. Available nitrogen was estimated by Kjeldhal method. Bulk Density was determined by Oven dry weight and volume of the core (Black, 1966). Saturated hydraulic conductivity was determined by constant water head method (Kult and Dricksen 1986). Available micronutrients and heavy metals were estimated as per procedure described by Atomic Absorption Spectrophotometric method (Page et al. 1982). Micronutrients and heavy metals in the soil are depicted in (Fig.2).

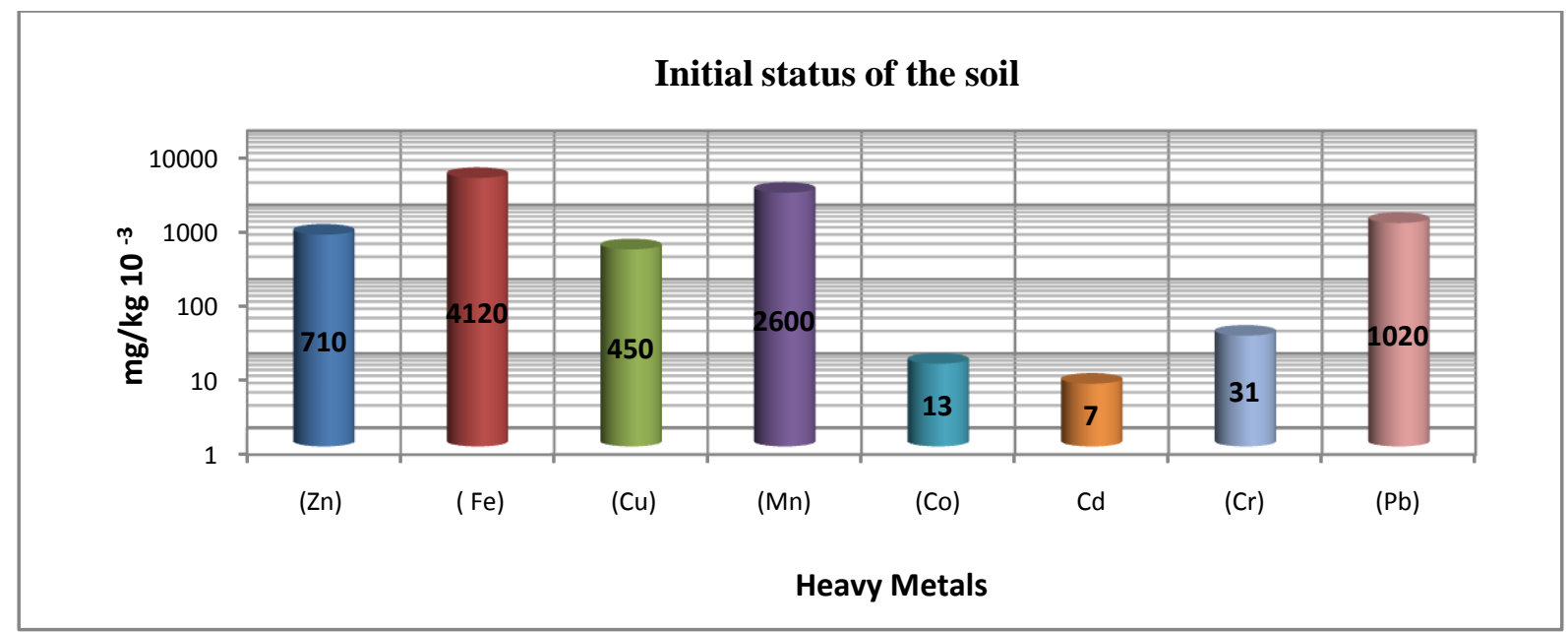

Fig.2: Available Micronutrients and heavy metal in Soil

\section{Results And Discussion}

\section{Quality DTSW and WW.}

The quality of irrigation water (DTSW and WW) was assessed for its suitability for irrigation with respect to their $\mathrm{pH}, \mathrm{EC}, \mathrm{SAR}$, carbonate, bicarbonate, calcium, magnesium, Sodium, BOD, COD, nitrogen, phosphate and potassium. Samples of the DTSW and WW were analyzed in the laboratory for their physico-chemical parameters are reported in Table 1 . The irrigation water of both the sources was slightly alkaline in reaction. The $\mathrm{pH}$ of the DTSW was (7.1) slightly lower than the WW, whereas salt content (EC $0.602 \mathrm{dS} \mathrm{m}^{-1}$ ) was higher than that of WW. Calcium was the dominant cation followed by magnesium and sodium, although the sodium content was slightly higher in DTSW. The sodium adsorption ratio (SAR) of both the water resources is much less than the critical limit. Carbonate and bicarbonate of the DTSW was slightly higher than the WW, whereas chloride content was 2 to 3 fold higher in DTSW than WW. On the basis of SAR both the water was suitable for irrigation. On the basis of BOD and COD, the DTSW was rated as suitable for irrigation purpose when compared with the prescribed limit of 100 and $250 \mathrm{mg} \mathrm{L}^{-1}$ for BOD and COD respectively. In case of all the major nutrients (NPK) they were slightly higher in DTSW but not significantly more than WW. Nitrogen was three times higher, phosphorus was five times more and potassium was slightly higher in DTSW. Available micronutrients and heavy metals in treated irrigation water are presented in Fig.3. 
Table 1. Characteristics of DTSW and WW used for irrigation

\begin{tabular}{|l|c|c|}
\hline \multicolumn{1}{|c|}{ Parameter } & DTSW & WW \\
\hline $\mathrm{pH}$ & $7.1 \pm 0.12$ & $7.5 \pm 0.76$ \\
\hline $\mathrm{EC}\left(\mathrm{dSm}^{-1}\right)$ & $0.602 \pm 0.18$ & $0.412 \pm 0.017$ \\
\hline SAR & $0.656 \pm 0.098$ & $0.615 \pm 0.056$ \\
\hline Carbonates $(\mathrm{CO} 3)\left(\mathrm{mg} \mathrm{L}^{-1}\right)$ & $0.57 \pm 0.068$ & $0.30 \pm 0.013$ \\
\hline Bicarbonates $\left(\mathrm{HCO}^{-}\right)\left(\mathrm{mg} \mathrm{L}^{-1}\right)$ & $3.81 \pm 0.23$ & $3.18 \pm 0.036$ \\
\hline Chlorides $\left(\mathrm{Cl}^{-}\right)\left(\mathrm{mg} \mathrm{L}^{-1}\right)$ & $3.68 \pm 0.98$ & $1.48 \pm 0.84$ \\
\hline Calcium $\left(\mathrm{mg} \mathrm{L}^{-1}\right)$ & $4.12 \pm 0.096$ & $2.68 \pm 0.09$ \\
\hline Magnesium $\left(\mathrm{mg} \mathrm{L}^{-1}\right)$ & $1.42 \pm 0.32$ & $0.72 \pm 0.09$ \\
\hline Sodium $\left(\mathrm{Na}^{-1} \mathrm{mg} \mathrm{L}^{-1}\right)$ & $1.09 \pm 0.022$ & $0.80 \pm 0.014$ \\
\hline BOD $\left(\mathrm{mg} \mathrm{L}^{-1}\right)$ & $4.14 \pm 0.32$ & $1.62 \pm 0.084$ \\
\hline COD $\left(\mathrm{mg} \mathrm{L}^{-1}\right)$ & $15 \pm 0.54$ & $5 . \pm 0.074$ \\
\hline TDS $\left(\mathrm{mg} \mathrm{L}^{-1}\right)$ & $399 \pm 0.67$ & $278 \pm 0.85$ \\
\hline Nitrogen $\left(\mathrm{mg} \mathrm{L}^{-1}\right)$ & $3.7 \pm 0.24$ & $1.1 \pm 0.098$ \\
\hline Phosphate $\left(\mathrm{mg} \mathrm{L}^{-1}\right)$ & $1.3 \pm 0.81$ & $0.26 \pm 0.087$ \\
\hline Potassium $\left(\mathrm{mg} \mathrm{L}^{-1}\right)$ & $0.32 \pm 0.07$ & $0.22 \pm 0.016$ \\
\hline
\end{tabular}

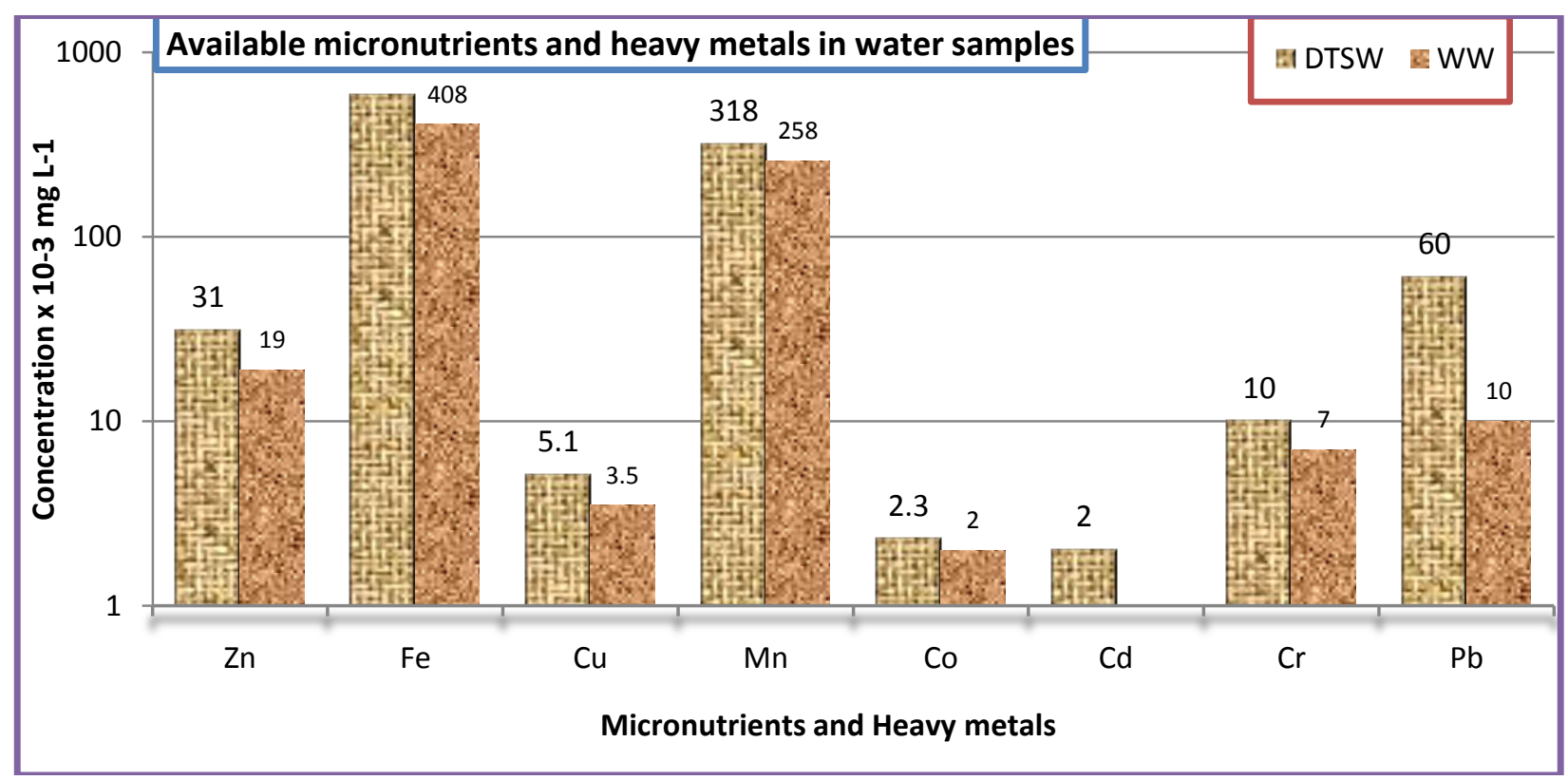

Fig.3: Available micronutrients and heavy metals in DSTW samples

\section{2: Crop Yield}

\section{A: Effect of treated sewage water irrigation on growth and yield of spinach}

The use of DTSW has favourably influenced the crop production; its continuous application for number of years may result in enrichment in top soils (Antolin et al. 2005). The yield of crop like spinach was significantly increased as recorded by DTSW over the WW irrigation (Table 2). 
Table 2. Effect of treated sewage water irrigation on growth and yield of spinach 2012-2013 20132014

\begin{tabular}{|c|c|c|c|c|c|c|c|c|c|}
\hline \multirow{2}{*}{$\begin{array}{c}\text { Treatmen } \\
\text { ts }\end{array}$} & \multicolumn{3}{|c|}{ Height $(\mathrm{cm})$} & \multicolumn{3}{c|}{ Green Yield $\left(\mathrm{kg} \mathrm{plot}^{-1}\right)$} & \multicolumn{3}{c|}{${\text { Yield }\left(\mathrm{t} \mathrm{ha}^{-1}\right)}^{2012-}$} \\
\cline { 2 - 11 } & $\begin{array}{c}2013- \\
2014\end{array}$ & Mean & $\begin{array}{c}2012- \\
2013\end{array}$ & $\begin{array}{c}2013- \\
2014\end{array}$ & Mean & $\begin{array}{c}2012- \\
2013\end{array}$ & $2013-2014$ & Mean \\
\hline $\begin{array}{c}\mathrm{T}_{1^{-}} \\
\mathrm{DTSW}\end{array}$ & 26.03 & 28.46 & $\begin{array}{c}27.2 \\
5\end{array}$ & 1.20 & 1.29 & 1.245 & 11.97 & 12.89 & 12.43 \\
\hline $\mathrm{T}_{2}-\mathrm{WW}$ & 23.91 & 25.67 & $\begin{array}{c}24.7 \\
9\end{array}$ & 0.99 & 1.06 & 1.025 & 9.95 & 10.39 & 10.17 \\
\hline $\mathrm{SE}(\mathrm{m}) \pm$ & 0.50 & 0.85 & -- & 0.04 & 0.04 & -- & 0.37 & 0.55 & -- \\
\hline $\mathrm{CD}$ at 5\% & 1.50 & 2.53 & -- & 0.11 & 0.12 & -- & 1.10 & 1.62 & -- \\
\hline F Test & Sig. & Sig. & -- & Sig & Sig. & -- & Sig & Sig. & -- \\
\hline
\end{tabular}

The significantly higher crop yield was recorded due to application of DTSW over WW irrigation. The DTSW contains large amount of nutrients and therefore could be used as a source of irrigation as Madyiwa et al. (2002), Ham et al (2007) as evident by their results. Spinach recorded highest mean yield $\left(12.43 \mathrm{tha}^{-1}\right)$. The height of spinach at the time of harvest (30 DAS) was found significantly higher in the case of irrigation by DTSW. Fresh spinach yield was observed to increase by 21.75 per cent over irrigation with well water. Ladwani et al. 2012; Gupta et al 1998; Thapliyal et al. 2011 also reported significantly higher yield of vegetables due to irrigation with domestic wastewater over ground water.

\section{3: Content of micronutrients and heavy metals in vegetables}

(a) Micronutrients: Concentration of the micronutrient in the spinach was not influenced significantly due to irrigation with DTSW. As depicted in Fig.4 concentration of micronutrients like $\mathrm{Zn}, \mathrm{Fe}, \mathrm{Cu}$, and $\mathrm{Mn}$ in the plant irrigated with the DTSW was observed slightly higher over the irrigation by WW. By and large accumulation of micronutrients due to irrigation with DTSW was well below the critical limits prescribed for the phytotoxicity of these micronutrients. Similar findings are in line with the results reported earlier by Madyiwa et al. (2002) for the soil irrigated with domestic sewage.

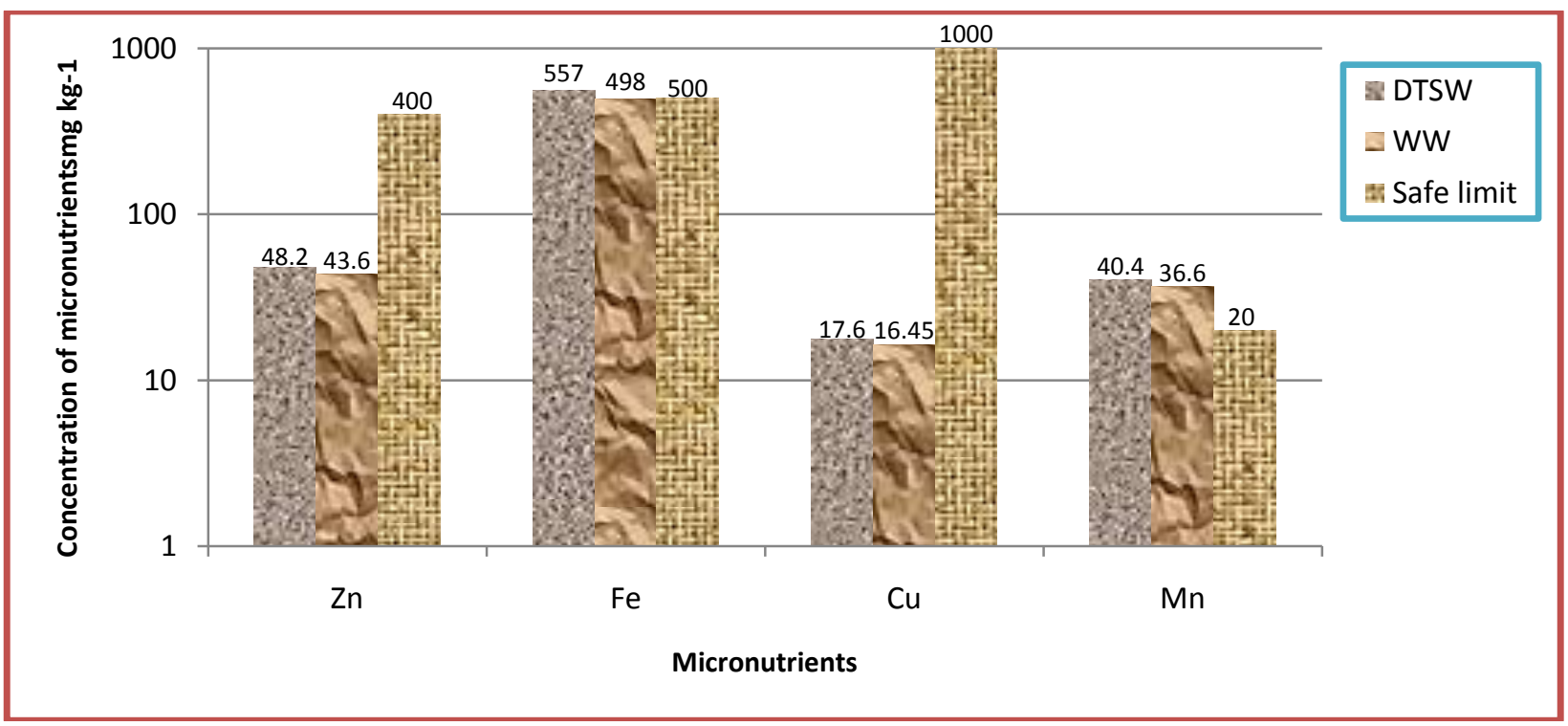

Fig.4: Micronutrients content in spinach after harvest 


\section{(b) Heavy metals content in spinach}

The data comprising to the heavy metals concentration in the spinach are as depicted in the Fig.5 revealed that the content of heavy metals viz., $\mathrm{Co}, \mathrm{Cd}, \mathrm{Cr}$ and $\mathrm{Pb}$ in the plant was not much accumulated and not influenced significantly due to irrigation with DTSW. Content of $\mathrm{Co}, \mathrm{Cd}, \mathrm{Cr}$ and $\mathrm{Pb}$ in spinach in the treatment of DTSW were slightly higher as compared to the WW irrigation.

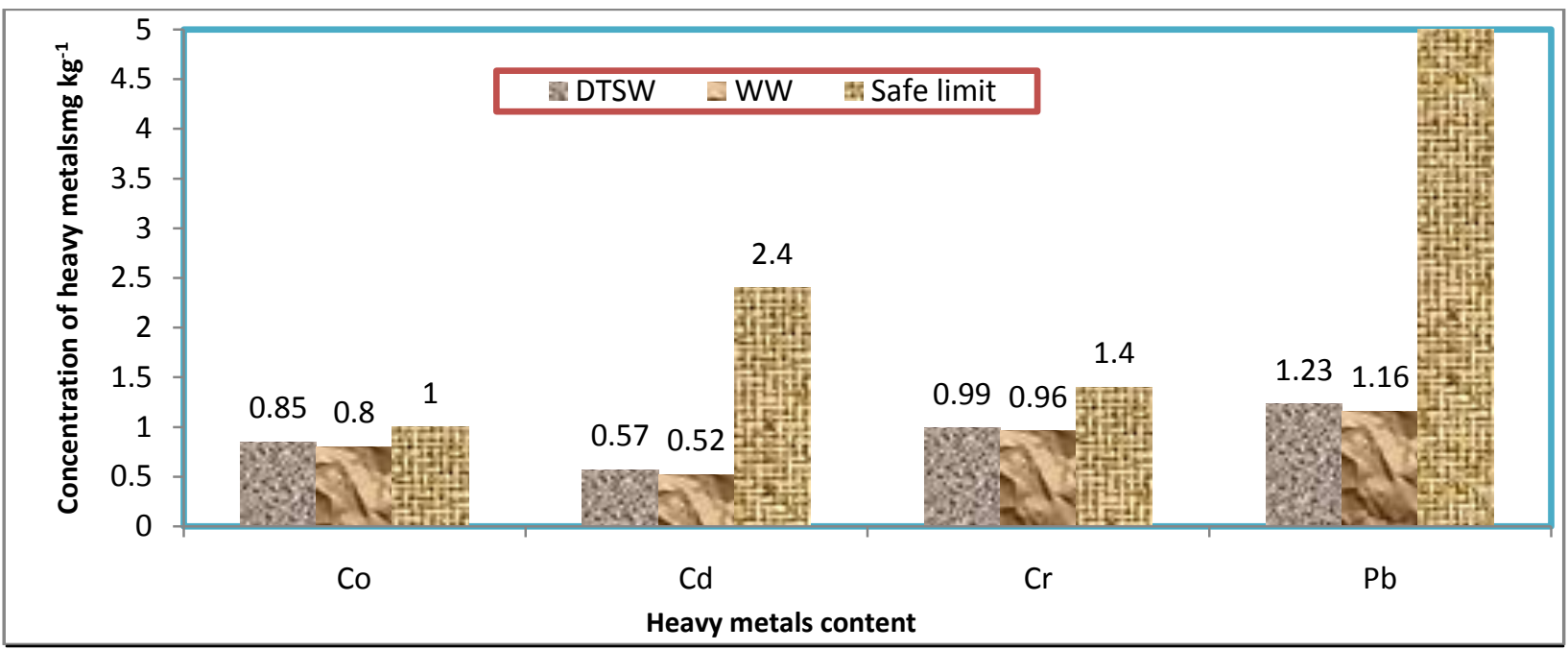

Fig. 5: Concentration of heavy metals in spinach after harvest

The mean heavy metals content in spinach due to irrigation with DTSW was lower than the critical limits prescribed for the phytotoxicity of these metals. The finding corroborates with the results reported earlier by Yadav et al. (2002) for the soil irrigated with DTSW.

\section{4: Changes in the physico-chemical soil properties after harvest of the spinach}

\section{(a) Chemical properties}

The results in relation to the chemical properties of soil after harvest of the spinach (Table 3a) noticed that the mean value of $\mathrm{pH}$ of the soil was found to be 7.82 in treatment of irrigation with DTSW whereas it was 7.93 in WW irrigation. Al Omran et al. (2011) noticed the similar finding of dropping of $\mathrm{pH}$ by use of treated sewage effluent as compared with well irrigation and initial value in soil.

Mean value of EC of soil was increased slightly with DTSW $\left(0.44 \mathrm{dS} \mathrm{m}^{-1}\right)$ as compared to WW irrigation $\left(0.315 \mathrm{dS} \mathrm{m}^{-1}\right)$ to spinach crop. This slight increase in EC might be attributed to content of the salts in sewage. Kalavrouziotis et al. (2008) also reported similar finding of increase of EC due to use of treated sewage water irrigation in soil as compared to ordinary irrigation water and initial status value. Yadav et al. (2002) noticed similar results stating use of sewage water for irrigation increased the soil electrical conductivity because of more salt content. The organic carbon content was not influenced statistically but irrigation with DTSW to spinach crops increased mean organic carbon content $\left(5.46 \mathrm{~g} \mathrm{~kg}^{-1}\right)$ as compared to WW irrigation $\left(5.30 \mathrm{~g} \mathrm{~kg}^{-1}\right)$. Wang et al. (2007) reported similar finding of increase in organic carbon in soil due to use of sewage water for irrigation. The mean value of available nitrogen in the soil was increased slightly by irrigation DTSW $\left(281.7 \mathrm{~kg} \mathrm{ha}^{-1}\right)$ and slightly reduced in treatment by WW irrigation $\left(273.6 \mathrm{~kg} \mathrm{ha}^{-1}\right)$. The increase in available nitrogen was noticed to the extent of 4.26 per cent by DTSW over the initial value of available nitrogen in soil after harvest of the spinach. The increased in mean 
value of available phosphorous in soil after harvest of the spinach was observed in treatment of irrigation with DTSW (17.77 kg ha $\left.{ }^{-1}\right)$ which was $\left(16.66 \mathrm{~kg} \mathrm{ha}^{-1}\right)$ in the treatment of the WW irrigation. The mean value of available potassium in soil after harvest of the spinach in the treatment of irrigation with the DTSW was found (442.0 kg ha $\mathrm{kg}^{-1}$ ) however WW irrigation $\left(433.15 \mathrm{~kg} \mathrm{ha}^{-1}\right)$ increased its availability in the soil. The increase in available potassium was noticed to the extent of 7.50 per cent by DTSW over the initial status, this finding are consistent with the Ladwani et al.(2012), Alikhasi et al. (2012) and Mandal et al. (2008).

Table 3.(a) Changes in the chemical properties of the soil irrigated with DTSW and WW after harvest of spinach during 2012-13 and 2013-14

\begin{tabular}{|c|c|c|c|c|c|c|c|c|c|c|c|c|c|c|c|c|c|c|}
\hline \multirow{3}{*}{ Treatments } & \multirow{2}{*}{\multicolumn{3}{|c|}{$\mathrm{pH}$}} & \multirow{2}{*}{\multicolumn{3}{|c|}{$\begin{array}{c}E C \\
\left(\mathrm{dS} \mathrm{m}^{-1}\right)\end{array}$}} & \multirow{2}{*}{\multicolumn{3}{|c|}{$\begin{array}{l}\text { Organic carbon } \\
\qquad\left(\mathrm{g} \mathrm{kg}^{-1}\right)\end{array}$}} & \multicolumn{9}{|c|}{ Nutrient (kg ha-1) } \\
\hline & & & & & & & & & & \multicolumn{3}{|c|}{$\mathrm{N}$} & \multicolumn{3}{|c|}{$\mathrm{P}$} & \multicolumn{3}{|c|}{ K } \\
\hline & $\begin{array}{c}2012- \\
13\end{array}$ & $\begin{array}{l}2013- \\
14\end{array}$ & Mean & $\begin{array}{c}2012- \\
13\end{array}$ & $\begin{array}{c}2013- \\
14\end{array}$ & Mean & $\begin{array}{c}2012- \\
13\end{array}$ & $\begin{array}{l}2013- \\
14\end{array}$ & Mean & $\begin{array}{c}2012- \\
13\end{array}$ & $\begin{array}{l}2013- \\
14\end{array}$ & Mean & $\begin{array}{c}2012- \\
13\end{array}$ & $\begin{array}{c}2013- \\
14\end{array}$ & Mean & \begin{tabular}{|c}
$2012-$ \\
13
\end{tabular} & \begin{tabular}{|c|}
$2013-$ \\
14
\end{tabular} & Mean \\
\hline $\mathrm{T}_{1}$ - DTSW & 7.85 & 7.78 & 7.82 & 0.43 & 0.45 & 0.44 & 5.41 & 5.51 & 5.46 & 279.6 & 283.8 & 281.7 & 17.22 & 18.34 & 17.77 & 435.7 & 448.3 & 442.0 \\
\hline $\mathrm{T}_{2}-\mathrm{WW}$ & 7.93 & 7.92 & 7.925 & 0.31 & 0.32 & 0.315 & 5.27 & 5.32 & 5.30 & 266.8 & 280.3 & 273.6 & 16.44 & 16.88 & 16.66 & 428.1 & \begin{tabular}{|l|}
438.2 \\
\end{tabular} & 433.15 \\
\hline Initial & 7.91 & 7.91 & 7.91 & 0.32 & 0.32 & 0.32 & 5.21 & 5.21 & -- & 270.2 & 270.2 & -- & 15.23 & 15.23 & -- & 417.0 & 417.0 & -- \\
\hline 'F' test & NS & NS & -- & NS & NS & -- & NS & NS & -- & NS & NS & -- & NS & NS & -- & NS & NS & -- \\
\hline $\operatorname{SEm}( \pm)$ & 0.21 & 0.08 & -- & 0.03 & 0.03 & -- & 0.13 & 0.06 & -- & 10.48 & 8.71 & -- & 1.56 & 1.23 & -- & 9.54 & 8.61 & -- \\
\hline
\end{tabular}

Table 3.(b) Changes in the physical properties of the soil irrigated with DTSW and WW after harvest of spinach during 2012-13 and 2013-14

\begin{tabular}{|c|c|c|c|c|c|c|}
\hline \multirow{2}{*}{ Treatments } & \multicolumn{3}{|c|}{ Bulk density $\left(\mathbf{M g ~ m}^{-\mathbf{3}}\right)$} & \multicolumn{3}{c|}{ Hydraulic conductivity $\left(\mathbf{c m ~ h r}^{-\mathbf{1}}\right)$} \\
\cline { 2 - 7 } & $2012-13$ & $2013-14$ & Mean & $2012-13$ & $2013-14$ & Mean \\
\hline $\mathrm{T}_{1}$ - DTSW & 1.32 & 1.28 & 1.30 & 1.50 & 1.47 & 1.485 \\
\hline $\mathrm{T}_{2}$-WW & 1.42 & 1.43 & 1.425 & 1.54 & 1.56 & 1.55 \\
\hline $\begin{array}{l}\text { Initial } \\
\text { status }\end{array}$ & $\mathbf{1 . 3 5}$ & $\mathbf{1 . 3 5}$ & -- & $\mathbf{1 . 5 2}$ & $\mathbf{1 . 5 2}$ & -- \\
\hline 'F' test & $\mathrm{NS}$ & $\mathrm{NS}$ & -- & $\mathrm{NS}$ & $\mathrm{NS}$ & -- \\
\hline SEm $( \pm)$ & 0.08 & 0.06 & -- & 0.11 & 0.10 & -- \\
\hline
\end{tabular}

\section{(b) Physical properties}

The data pertaining to the physical properties of soil viz., bulk density and hydraulic conductivity are presented in Table 3(b).

The bulk density of soil was not influenced significantly due to irrigation with DTSW. The mean bulk density was found to be $1.30 \mathrm{Mg} \mathrm{m}^{-3}$ in treatment of irrigation with DTSW which reduced with initial and with the value $\left(1.425 \mathrm{Mg} \mathrm{m}^{-3}\right)$ in treatment WW irrigation after harvest of the spinach. Bulk density was slightly decreased in soil irrigated with DTSW over the WW and initial status of the soil. Lado et al. (2002) also observed the decrease in bulk density of soil in treated sewage water.

The mean value of hydraulic conductivity found to be decrease slightly due to irrigation with DTSW $\left(1.485 \mathrm{~cm} \mathrm{hr}^{-1}\right)$ while with WW irrigation $\left(1.55 \mathrm{~cm} \mathrm{hr}^{-1}\right)$. It might be attributed as DTSW contains the suspended solid particles and therefore this water irrigation can have direct effect on hydraulic conductivity by plugging of capillary pores of soil by suspended solid particle carried by the irrigating 
effluent. The findings are consistent with the Vinten et al.(1983); Lavy et al.(1999) and Lado et al. (2002) in review study of DTSW irrigation effect on soil hydraulic properties in the arid and semiarid zones.

\section{(c) Micronutrients}

The data pertaining to micronutrients content in soil after harvest of spinach (Table 4) indicated that the content of micronutrients in the soil was not influenced significantly due to irrigation with DTSW. The available $\mathrm{Zn}, \mathrm{Fe}, \mathrm{Cu}$, and $\mathrm{Mn}$ were found were slightly higher in the treatment of DTSW as compared to irrigation with WW. By and large accumulation of micronutrients due to irrigation with DTSW was well below the critical limits prescribed for the phytotoxicity of these micronutrients. Al Omron et al. (2011) reported the similar result of increase of micronutrients in the soil by use of treated sewage water for irrigation.

Table 4. Micronutrients in the soils

\begin{tabular}{|c|c|c|c|c|c|c|c|c|c|c|c|c|}
\hline \multirow{3}{*}{$\begin{array}{l}\text { Treatmen } \\
\text { ts }\end{array}$} & \multicolumn{12}{|c|}{ Micronutrients } \\
\hline & \multicolumn{3}{|c|}{$\mathbf{Z n}$} & \multicolumn{3}{|c|}{$\mathbf{F e}$} & \multicolumn{3}{|c|}{$\mathbf{C u}$} & \multicolumn{3}{|c|}{ Mn } \\
\hline & $\begin{array}{r}2012- \\
13 \\
\end{array}$ & $\begin{array}{c}2013- \\
14 \\
\end{array}$ & Mean & $\begin{array}{r}2012 \\
-13 \\
\end{array}$ & $\begin{array}{r}2013 \\
-14 \\
\end{array}$ & $\begin{array}{c}\text { Mea } \\
n\end{array}$ & $\begin{array}{r}2012 \\
-13 \\
\end{array}$ & $\begin{array}{c}2013- \\
14 \\
\end{array}$ & $\begin{array}{c}\text { Mea } \\
n\end{array}$ & $\begin{array}{r}2012- \\
13 \\
\end{array}$ & $\begin{array}{c}2013- \\
14 \\
\end{array}$ & Mean \\
\hline $\mathrm{T}_{1}-\mathrm{DTSW}$ & 0.74 & 0.77 & 0.755 & 4.3 & 4.3 & 4.32 & 0.5 & 0.54 & 0.52 & 2.65 & 2.78 & 2.72 \\
\hline $\mathrm{T}_{2}-\mathrm{WW}$ & 0.68 & 0.69 & 0.685 & 4.1 & 4.1 & 4.15 & 0.4 & 0.43 & 0.42 & 2.62 & 2.67 & 2.64 \\
\hline 'F' test & NS & NS & -- & NS & NS & -- & NS & NS & -- & $\mathbf{N S}$ & NS & -- \\
\hline $\operatorname{SEm}( \pm)$ & 0.08 & 0.06 & -- & 0.0 & 0.1 & -- & 0.0 & 0.03 & -- & 0.08 & 0.08 & -- \\
\hline $\begin{array}{l}\text { Initial } \\
\text { ctatuc }\end{array}$ & \multicolumn{2}{|c|}{0.71} & -- & \multicolumn{2}{|c|}{4.12} & -- & \multicolumn{2}{|c|}{0.45} & -- & \multicolumn{2}{|c|}{2.60} & -- \\
\hline Safe limit & \multicolumn{2}{|c|}{2.00} & -- & \multicolumn{2}{|c|}{10.00} & -- & \multicolumn{2}{|c|}{5.00} & -- & \multicolumn{2}{|c|}{5.00} & -- \\
\hline
\end{tabular}

\section{(d) Heavy Metals}

The heavy metal accumulation content in the soil after harvest of spinach (Table 5) revealed that the content of extractable heavy metals viz., $\mathrm{Co}, \mathrm{Cd}, \mathrm{Cr}$ and $\mathrm{Pb}$ was not much accumulated due to irrigation with DTSW in soil after harvest of the spinach.

Table 5. Heavy metals in the soils

\begin{tabular}{|c|c|c|c|c|c|c|c|c|c|c|c|}
\hline \multirow{3}{*}{$\begin{array}{l}\text { Treatment } \\
\text { s }\end{array}$} & \multicolumn{11}{|c|}{ Heavy metals } \\
\hline & \multicolumn{3}{|c|}{ Co } & \multicolumn{3}{|c|}{$\mathrm{Cd}$} & \multicolumn{3}{|c|}{$\mathrm{Cr}$} & \multicolumn{2}{|c|}{$\mathrm{Pb}$} \\
\hline & 2012- & 2013- & Mean & 2012- & 2013- & Mean & 2012- & $2013-$ & Mean & $2012-$ & 2013 \\
\hline $\mathrm{T}_{1}$ - DTSW & 0.019 & 0.023 & 0.021 & 0.011 & 0.016 & 0.0135 & 0.043 & 0.055 & 0.049 & 1.1 & 1.22 \\
\hline $\mathrm{T}_{2}-\mathrm{WW}$ & 0.017 & 0.018 & 0.0175 & 0.009 & 0.011 & 0.010 & 0.034 & 0.036 & 0.035 & 1.05 & 1.09 \\
\hline 'F' test & NS & NS & -- & NS & NS & -- & NS & NS & -- & NS & NS \\
\hline $\operatorname{SEm}( \pm)$ & 0.01 & 0.0 & -- & 0.0 & 0.0 & -- & 0.0 & 0.0 & -- & 0.03 & 0.05 \\
\hline Initial & \multicolumn{2}{|c|}{0.013} & -- & \multicolumn{2}{|c|}{0.007} & -- & \multicolumn{2}{|c|}{0.031} & -- & \multicolumn{2}{|c|}{1.02} \\
\hline Safe limit & \multicolumn{2}{|c|}{2.000} & -- & \multicolumn{2}{|c|}{0.500} & -- & \multicolumn{2}{|c|}{1.000} & -- & \multicolumn{2}{|c|}{5.00} \\
\hline
\end{tabular}

The accumulation of $\mathrm{Co}, \mathrm{Cd}, \mathrm{Cr}$ and $\mathrm{Pb}$ was as depicted in Table.5. Heavy metals in soil due to irrigation of DTSW were well below the safe limits in soil. Emongor and Ramolemana (2004) reported the similar finding in use of treated sewage water for irrigation of the crop. Similarly Datta et al. (2000) and Surdyk et al. (2010) reported consistent result of accumulation of heavy metals in the soil after the irrigation with treated water. 


\section{(e) Pathogenic count in DTSW}

As revealed in the table 6 pathogenic counts in the two samples of the raw sewage water and two samples of DTSW are studied and as per finding the faecal colliform are more than the recommended revised microbiological guidelines for treated wastewater use in agriculture. A Bulletin of the World Health Organization, 2000, 78(9) therefore treated sewage water is suitable for the irrigation to the field crops except the vegetables which can be eaten raw or uncooked vegetable used in the food.

Table 6. Pathogenic count in DTSW

\begin{tabular}{|c|c|c|c|c|c|c|c|}
\hline \multirow{3}{*}{$\begin{array}{l}\text { Sample } \\
\text { No }\end{array}$} & \multicolumn{7}{|c|}{ Parameter. } \\
\hline & $\begin{array}{l}\text { Param } \\
\text { ters }\end{array}$ & $\begin{array}{l}\text { Faecal } \\
\text { colliform }\end{array}$ & $\begin{array}{l}\text { Salmonell } \\
\text { a }\end{array}$ & $\begin{array}{l}\text { Shigella } \\
\text { spp. }\end{array}$ & $\begin{array}{l}\text { Vibrio } \\
\text { Cholerae }\end{array}$ & $\begin{array}{l}\text { Entamoeba } \\
\text { Histolytica }\end{array}$ & $\begin{array}{l}\text { Ascaris } \\
\text { Lubricold }\end{array}$ \\
\hline & $\begin{array}{l}\text { Metho } \\
\text { d }\end{array}$ & APHA & $\begin{array}{l}\text { IS5887 } \\
\text { (part3) }\end{array}$ & $\begin{array}{l}\text { IS5887 } \\
\text { (part }\end{array}$ & $\begin{array}{ll}\begin{array}{l}\text { IS5887 } \\
(\text { part }\end{array} & \text { V) }\end{array}$ & $\begin{array}{l}\text { By } \\
\text { Microscopy }\end{array}$ & $\begin{array}{l}\text { By } \\
\text { Microsco }\end{array}$ \\
\hline \multirow{2}{*}{$\begin{array}{l}\text { Sample } \\
\text { No-1 } \\
\text { (SW) }\end{array}$} & $\begin{array}{l}\text { Result } \\
\mathrm{S}\end{array}$ & $3.5 \times 10^{6}$ & Absent & Absent & Absent & ND & ND \\
\hline & Unit & MPN/100 & $/ 100 \mathrm{ml}$ & $/ 100 \mathrm{ml}$ & $/ 100 \mathrm{ml}$ & / lit. & / lit. \\
\hline \multirow{2}{*}{$\begin{array}{l}\text { Sample } \\
\text { No-2 } \\
\text { (SW) }\end{array}$} & $\begin{array}{l}\text { Result } \\
\mathrm{S}\end{array}$ & $3.5 \times 10^{6}$ & Absent & Absent & In Absent & ND & ND \\
\hline & Unit & $\begin{array}{l}\mathrm{MPN} / 100 \\
\mathrm{ml}\end{array}$ & $/ 100 \mathrm{ml}$ & $/ 100 \mathrm{ml}$ & $/ 100 \mathrm{ml}$ & / lit. & / lit. \\
\hline \multirow{2}{*}{$\begin{array}{l}\text { Sample } \\
\text { No-3 } \\
\text { (TSW) }\end{array}$} & $\begin{array}{l}\text { Result } \\
\text { S }\end{array}$ & $5.4 \times 10^{5}$ & Absent & Absent & Absent & ND & ND \\
\hline & Unit & MPN/100 & $/ 100 \mathrm{ml}$ & $/ 100 \mathrm{ml}$ & $/ 100 \mathrm{ml}$ & / lit. & / lit. \\
\hline \multirow{2}{*}{$\begin{array}{l}\text { SampleNo- } \\
4 \\
(\mathrm{TSW})\end{array}$} & $\begin{array}{l}\text { Result } \\
\mathrm{S}\end{array}$ & $5.4 \times 10^{5}$ & Absent & Absent & Absent & ND & ND \\
\hline & Unit & $\begin{array}{l}\mathrm{MPN} / 100 \\
\mathrm{ml}\end{array}$ & $/ 100 \mathrm{ml}$ & $/ 100 \mathrm{ml}$ & $/ 100 \mathrm{ml}$ & / lit. & / lit. \\
\hline
\end{tabular}

\section{(f) Microbial count in soil after harvest of spinach}

The data pertaining to the microbial count viz., bacterial population, fungal population and antinomycetes population in soil after harvest of cotton are presented in Table 7. The results revealed that the bacterial, fungal and antinomycetes population in soil after harvest of crop was found slightly higher in soil with irrigation of DTSW as compared to irrigation with WW.

Table 7.Changes in the microbial properties of the soil irrigated with DTSW and WW after harvest of the spinach

\begin{tabular}{|l|c|c|c|}
\hline Treatments & $\begin{array}{c}\text { Bacterial } \\
\text { population }\left(\mathrm{cfux} 10^{6}\right)\end{array}$ & $\begin{array}{c}\text { Fungal population } \\
\left(\mathrm{cfux} 10^{4}\right)\end{array}$ & $\begin{array}{c}\text { Antinomycetes } \\
\text { Population } \\
(\text { cfux 10 })\end{array}$ \\
\hline T1-Treated water & 41.00 & 8.89 & 29.67 \\
\hline T2-Well water & 24.67 & 3.04 & 10.33 \\
\hline SE $(\mathrm{m}) \pm$ & 0.54 & 0.22 & 1.55 \\
\hline CD at $5 \%$ & 1.44 & 0.579 & 4.09 \\
\hline
\end{tabular}


(f) Pathogenic Count in spinach crop irrigated with treated sewage water.

As revealed in the table 7, pathogenic counts in the two samples of the spinach crop irrigated by treated sewage water are studied and as per finding the Total colliform, faecal colliform and E coli are in negligible quantity in spinach crop as compared with the Government and Industry Standards for Bacterial Indicator Organisms in Selected Foods and in Water.

Table.8.Pathogenic Count in spinach crop irrigated with treated sewage water

\begin{tabular}{|c|l|c|c|c|}
\hline Sr. No & Name of Pathogen & Method & Unit & Result \\
\hline 1 & Total colli forms & IS 5401Incubated at 370 C for 24 hrs & Cfu /g & Less than 10 \\
\hline 2 & Feacal Colliform & B.M.A. & MPN/g & Less than 3 \\
\hline 3 & E.Coli & IS 5887 (Part 1) & $/ \mathrm{g}$ & Absent \\
\hline
\end{tabular}

(Reference: Government and Industry Standards for Bacterial Indicator Organisms in Selected Foods and in Water)

\section{Conclusion}

If land with suitable topography, soil characteristics and drainage is available, DTSW can put good use as a source of both irrigation water and plant nutrients. DTSW contains high amount of organic matter, nutrients and some heavy metals which are toxic to plants beyond a certain limit. The concentrations of micronutrients ( $\mathrm{Zn}, \mathrm{Fe}, \mathrm{Cu}$, and $\mathrm{Mn}$ ) and heavy metals like $\mathrm{Co}, \mathrm{Cd}, \mathrm{Cr}$ and $\mathrm{Pb}$ in spinach and soil irrigated with DTSW was observed well below the critical limits prescribed for the phytotoxicity of these metals. Application of DTSW increased the yield of spinach compared to irrigation with WW; it also increases total N, P, K and organic carbon content of soil. In India, encountering the problems of water scarcity and high cost of fertilizers, domestic treated sewage water could be successfully used for irrigation. Findings indicate that, DTSW with physical, chemical and biological treatment through wetland engineering technique could increase water resources for irrigation may prove to be beneficial for agricultural production in sustainable environment.

\section{References}

[1] Al Omron A M ; El-Maghraby S E; Nadeem M E A; El-Eter A M; Al- Mohani H. 2011. Long term effect of irrigation with the treated sewage effluent on some soil properties of AlHassa Governorate, Saudi Arabia J. Saudi Society of Agricultural Sciences xxx, xxx-xxx.

[2] Alikhasi, M; Kouchakzadeh M. and Baniani E. 2012. The effect of treated municipal wastewater Irrigation in non-agricultural soil on cotton plant. J. Agri. Sci. Tech. 14: 1357-1364.

[3] Al-Rashed M.F and Sherif, M.M.2000. "Water resources in the GCC countries: an overview", Water Res. Manag, vol. 14 (1) : 59-73.

[4] Al-Salem S S. 1996. "Environmental considerations for wastewater reuse in agriculture. Water Sci. Technol33 (10-11):345-353.

[5] Antolın M; Carmen I; Pascual C; Garcı A; Polo and Sanchez- Diaz M. 2005. Growth, yield and solute content of barley in soils treated with sewage sludge under semiarid Mediterranean conditions. Field Crops Research 94:224-237. 
[6] APHA (American Public Health Association), Standard Methods for the examination of water and wastewater. American Public Health Association, Washington, DC. 1995.

[7] Brar M S; Mahli S S; Singh A P; Arora C L and Gill KS. 2000. Sewer water irrigation effects on some potentially toxic trace elements in soil and potato plants in north western India. Can J Soil Sci. 80: 465-71.

[8] Datta S P; Biswas D R; Sarang N; Ghash S K and Rattan R R. 2000.Effect of long-term application of sewage effluents on organic carbon, bioavailable phosphorus, potassium and heavy metal status of soils and content of heavy metals in crops grown thereon. J. Indian Soc. Soil Sci.48 (4): 836-839.

[9] Emongor V A and Ramolemana. 2004. Treated sewage effluent (water) potential to be used for horticultural production in Botswana. Physics and Chemistry of the Earth. 29:1101-1108.

[10] Gregory A. 2000. "Strategic direction of water recycling in Sydney", Proceeding Of the First Symposium Water Recycling, Australia Adelaide, 19-20: 35-41.

[11] Gupta A P; Narwal R P and Antil R S.1998. Sewer water composition and its effect on soil properties. Bio-resource Ethnology65: 171-173.

[12] Ham J H; Yoon C G; Jeon J H and H C Kim. 2007. Feasibility of a constructed wetland and wastewater stabilization pond system as a sewage reclamation system for agricultural reuse in a decentralized rural area. Water Science and Technology, 55 (1-2): 503-511.

[13] Kalavrouziotis I K; Robolas P; Koukoulakis P H and Papadopoulos A. H. 2008. Effects of municipal reclaimed wastewater on the macro and micro elements status of soil. Brassica oleracea var. Italica and B. oleracea var. gemmifera. Agricultural Water Management95 (4): 419-426.

[14] Lado M and Meni Ben-Hur. 2002. Treated domestic sewage irrigation effects on soil hydraulic properties in arid and semiarid zones: A review metal contents of soils under vegetables in Harare, Zimbabwe. Agriculture, Ecosystems and Environment 107:151-165.

[15] Ladwani K D; Ladwani K D; Manik V. and D. S. Ramteke, 2012. Impact of domestic waste water irrigation on soil properties and crop yield. International J. of Scientific and Research Publications2(10):1-7.

[16] Levy G J; Rosenthal A; Tarchitzky J; Shainberg I and Chen Y.1999. Soil hydraulic conductivity changes caused by irrigation with reclaimed waste water. J. of Alliance of crop, soil and environmental science societies 28 (5): 1658- 1664.

[17] Mandal, U. K.; Warrington D.N; Bhardwaj A.K; Bar-Tal A; Kautsky L; Minz D. and Levy G.J. 2008. Evaluating impact of irrigation water quality on a calcareous clay soil using principal component analysis. Geoderma 144: 189-197.

[18] Madyiwa S; Chimbari M; Nyamangara J and Bangira C. 2002. Cumulative effects of sewage sludge and effluent mixture application on soil properties of a sandy soil under a mixture of star and kikuyu grasses in Zimbabwe. Physics and Chemistry of the Earth 27:747-753. 
[19] Mohammad M.J and Mazahreh N. 2003. "Changes in soil fertility parameters in response to irrigation of forage crops with secondary treated wastewater", Comm. Soil Sci. Plant Anal, 34 (9 \&10), pp. 1281-1294.

[20] Page A L; Miller RH and Kenny DR. 1982. Methods of soil analysis. Parts I and II.Madison, WI, USA: Am Soc Agron.

[21] Rutkowski T L; Raschid-Sally S and Buechler. 2006 "Wastewater irrigation in the developing world - Two case studies from the Kathmandu Valley in Nepal", Agric Water Manage. 88, 2006, pp. 83-91.

[22] Surdyk, N; Cary L; Blagojevic S; Jovanovic Z; Stikic R;.Vucelic-Radovic B; Zarkovic B; Sandei L; Pettenati M. and Kloppmann W. 2010. Impact of irrigation with treated low quality water on the heavy metal contents of a soil crop system in Serbia. Agricultural Water Management98(3): 451-457.

[23] Thapliyal A; Vasudevan P; Dastidar M G; Tandon M and Mishra S. 2011.Irrigation with domestic wastewater: Responses on growth and yield of ladyfinger Abelmoschus esculentus and on soil nutrients.J. Environ. Biol.32: 645-651.

[24] U.S. Environmental Protection Agency (USEPA). U.S. EPA. Offices of water and wastewater and compliance (Ed.) Guidelines for water reuse. U.S. EPA, Washington. WA State Water Strategy, 1992.

[25] Vinten A. J; Mingelgrin A U and Yaron B. 1983. The effect of suspended solids in wastewater on soil hydraulic conductivity: II. Vertical distribution of suspended solids. $J$. Alliance of crop, soil and environmental science societies47 (3): 408-412.

[26] Wang Jun-feng; Wang Gen-xu and Wanyan Hua. 2007. Treated waste water irrigation effect on soil, crop and environment: Waste water recycling in the loess area of China. J. Environmental Sciences. 19:1093-1099.

[27] Weber B; Avnimelech Y and Juanico M. 1996 "Salt enrichment of municipal sewage new prevention approaches in Israel. Environ. Manag20 (4), pp. 487-495.

[28] Yadav R K ; Goyal B; Sharma R K; Dubey S K and Minhas P S. 2002. Post-irrigation impact of domestic sewage effluent on composition of soils, crops and ground water- A case study. Environment International. 28(6): 481-486. 